This month sees the start of a New Year, with 2021 brim full of optimism from the development of a SARS-CoV-2 vaccine and the inauguration of a new US president, with both offering a possibly for the return to some degree of normality. With this issue of Airwaves we look back on the recent election and forward to the next year with renewed optimism.

\section{A SONG OF HOPE}

Brimful of Asha describes the Indian film industry, in particular Asha Bhosle, whose name means hope in Hindi, and whose Bollywood songs were filled with messages of hope. So does the manuscript by $\mathrm{Ra}$ and colleagues (see page 61) fill us with hope for 2021? They describe 213 patients who were positive for SARS-CoV-2, of who 19\% had no symptoms. After a median of 2 weeks approximately half of asymptomatic patients and two-thirds of symptomatic cases were still positive by PCR and there was no significant difference between the levels of a range viral genes in either asymptomatic or symptomatic people. So this offers hope to a large number people that even if they get infected they may not develop any symptoms even 2 weeks after becoming positive. However, it also highlights the risk that asymptomatic people could in theory transmit SARS-CoV-2 as their viral levels in the upper airways were almost the same as those with symptoms. So here we have to disagree with Cornershop, and we do care about Government warning

"Bout their promotion of the simple life, And the dams they're building", because they will help us bring the pandemic to an end (hopefully in 2021).

\section{ELECTIONS RALLIES AND MRI BRING MUSIC TO OUR EARS}

When he was only 7 years old, Donald Trump is alleged to have punched his music teacher. Almost seventy years later, the former president relied heavily on music to whip up the crowd at his campaign rallies. In this month's Thorax, the MUSIC study (see page 44) describes the use of MRI to image the upper airway in children who have had surgery for laryngotracheal stenosis. The technique allows measurements of the airway lumen during static and dynamic scans - the latter including inspiration and phonation. Compared with healthy volunteers, $81 \%$ of patients had vocal cord thickening. Dynamic scans showed both incomplete vocal cord abduction during inspiration and incomplete adduction during phonation. There was no sign of poor vocal cord function in the recordings belted out at trump rallies - including Queen singing "we are the champions". We can only speculate what Freddie
Mercury would have thought of being co-opted to "make America great again"...

\section{WORKING NIGHTS LEADS TO TWITTERING AND WHEEZING}

Former president Donald Trump habitually sent tweets in the small hours of the morning - often written in capital letters. His communications team would spend the daylight hours clearing up the resulting mess. However, the ill effects of night shift working can be seen in society more widely. In this month's journal, Maidstone and colleagues (see page 53) describe cross-sectional relationship between shift work and prevalent asthma, using data from the UK Biobank. The risk of moderate to severe asthma was increased in permanent night shift workers and further increased in "morning chronotypes" working irregular shifts, including nights. So night shift working can have negative effects in both the airways and the "Twittersphere". Perhaps retirement will bring an end to $2 \mathrm{am}$ tweets from the former president?

\section{CORONA IS NOT THE ONLY VIRUS...}

Joe Biden was elected the 46th US president with a pledge to tackle the SARS-CoV-2 pandemic. New approaches will be needed to tackle emerging respiratory viral threats as respiratory viruses including respiratory syncytial virus and influenza, as well as coronaviruses continue to plague human populations. In this edition of Thorax (see page 64) Pearson and colleagues present intriguing data showing that chloride transport through TMEM16A may be a key requirement for human respiratory syncytial virus replication and inhibition of TMEM16A may be a new target for antiviral therapies.

\section{HELLIONS AGAINST THE WALL}

There are many things that improve your quality of life (QoL). We are optimistic that vaccines and Joe Biden are just two of the things that will improve our QoL in 2021, and music and film are a couple more things which should improve as the year goes on. So how can you measure it? Hellions wrote a song called Quality of Life, and having listened to it the most simple of Visual Analogue scores will suffice in this instance. However, Against the Wall is a film, also known as Quality of Life, about graffiti artists in the Mission District of San Francisco. Having wandered around the Mission looking at these numerous works of art a more nuanced questionnaire approach might work better in this circumstance. In this issue of Thorax (see page 37) Tsai and colleagues assessed the QoL of 1816 patients with Interstitial Lung Disease from the CAnadian REgistry for Pulmonary Fibrosis to validate the Minimal Important Difference between the European Quality of Life 5-Dimensions 5-Levels questionnaire (EQ-5D-5L) and its associated Visual Analogue Scale (EQ-VAS) scores. They found the scores were strongly associated with dyspnoea but not with lung function. They suggest the scores from these tools are valid in this patient group and will help design clinical trials going forward. We believe that in this patient group, who so often find their backs against the wall, tools such as these will be invaluable for developing better treatments.

\section{FROM POLITICS TO ORTHOPAEDICS}

President elect Joe Biden in the lead up to the election was confident that there were no fractures in his party. Fractures are however a problem reported by Chalitsios and colleagues in this month's journal (see page 21) - using two large population-based nested case control studies of people with asthma. The authors describe a positive dose response relationship between cumulative corticosteroid exposure (oral and inhaled) and an risk of fragility fractures and osteoporosis.

\section{THE OPTIMISTIC FOCUS}

The internet and book shops are full of self-help advice on how to become an optimist and adopt a more optimistic approach to life, and there really are many reasons to be optimistic for 2021 . We at Thorax believe that Respiratory Medicine should be brimful of optimism as our research pages show month after month our efforts to focus on solutions to problems, challenge negativity, promote positivity and identify a range of positive role models. A wonderful example is demonstrated by Guillotin and colleagues (see page 73 ) who focus on understanding the nature of the fibroblastic focus using transcriptional analysis from laser captures diseased tissue. Using weighted gene co-expression network analysis, overcoming challenges associated with control tissue, they identify key molecular pathways that lead to the development of fibrosis and identify further molecular targets for therapeutic intervention. Reasons to be cheerful part 5!

\section{NAIL DAMAGE DUE TO ELECTIONS AND LUNG DISEASE}

Many of us were biting our nails on US election night and the days after. A different form of nail damage is shown in our featured image this month. Turn to page 102 to test your diagnostic skills.

Funding The authors have not declared a specific grant for this research from any funding agency in the public, commercial or not-for-profit sectors.

Competing interests None declared.

Patient consent for publication Not required.

Provenance and peer review Commissioned; internally peer reviewed.

(C) Author(s) (or their employer(s)) 2021. No commercial re-use. See rights and permissions. Published by BMJ. 